\title{
PRVNÍ ABSOLVENTKY - LÉKAŘKY ŽIDOVSKÉHO PŮVODU Z PRAŽSKÝCH UNIVERZIT A JEJICH KARIÉRNÍ MOŽNOSTI MEZI SVĚTOVÝMI VÁLKAMI
}

\author{
IVANA EBELOVÁ - MILADA SEKYRKOVÁ
}

\section{THE FIRST FEMALE PHYSICIANS OF JEWISH ORIGIN GRADUATING FROM PRAGUE UNIVERSITIES AND THEIR CAREER OPPORTUNITIES BETWEEN THE WORLD WARS}

Given the extent and state of surviving source materials, it is rather difficult to satisfactorily document the involvement of women of Jewish origin in academic education and their subsequent careers in science and practice relevant to the qualification they had achieved. This study therefore focuses on particular cases from the Bohemian Lands related mainly to medical studies and medical practice. We also include some examples of Jewish women with degrees in natural sciences and philosophy. Given that, save for a handful of exceptions, intellectuals of Jewish origin studied at the German University in Prague, this contribution to some extent also reflects the environment of the German University, especially in the first two decades of the twentieth century. Some of the differences between the situation at the Czech and German university in Prague are then highlighted by comparisons.

Keywords: Jewish female physicians - Prague universities - twentieth century

DOI: $10.14712 / 23365730.2021 .2$

\section{Úvodem}

Bezmála do konce 18. století bylo studentům židovského vyznání v habsburské monarchii zapovězeno studium na tamních univerzitách. Ty se jim otevřely teprve v roce 1781 . $^{1}$ Chlapci mohli začít studovat filozofické přípravky a poté přejít v př́ípadě zájmu na práva nebo medicínu, což také v hojné míře činili. ${ }^{2}$ To však byl pouze jeden z prvních kroků na cestě k postupné emancipaci obyvatel židovského původu. Trvalo ještě několik desetiletí, než byla v revolučním období 1848-1849 zrušena poslední ghetta, stejně jako odstraněna řada restriktivních opatření (toleranční daň, familiantský zákon). ${ }^{3}$ Teprve ale až prosinco-

1 Viz dvorský dekret z 18. ř́jna 1781. Handbuch aller unter der Regierung des Kaisers Joseph des II. für die k. k. Erbländer ergangenen Verordnungen und Gesetze in einer sistematischen Verbindung, enthält die Verordnungen und Gesetze vom Jahre 1780 bis 1784, IV, Wien 1785, s. 62-65.

2 Ivana EBelová, Židé a josefinské školské reformy. Židovští studenti na pražské univerzitě od osmdesátých let 18. století do rozdělení univerzity v roce 1882, Český časopis historický (dále ČČH) 112/4, 2014, s. 655-680.

3 K reformám v letech 1848-1849, jež se týkají židovského obyvatelstva a měly zásadní význam pro jeho emancipaci, viz Tomáš PĚKnÝ, Historie Židi̊ v Čechách a na Moravě, Praha 2.2001, s. 117-128. 
vá ústava $\mathrm{z}$ roku 1867, tvořená sedmi ř́šskými zákony ${ }^{4} \mathrm{~s}$ platností pro předlitavskou část monarchie, zaručovala jedním z nich, říšským zákonem č. 142/1867, tedy zákonem o všeobecných občanských právech, všem obyvatelům Předlitavska svobodu vyznání, osobní svobodu a rovnost všech občanů před zákonem bez ohledu na jejich etnický či náboženský původ. Na základě tohoto zákona se tedy i Židům dostalo rovnocenného postavení s ostatními obyvateli státu. ${ }^{5}$

V roce 1882 došlo $\mathrm{k}$ zásadní změně ve vysokoškolském systému v českých zemích. Českým politikům se na říšské radě podařilo prosadit zákon o rozdělení pražské univerzity na českou a samostatnou německou Karlo-Ferdinandovu univerzitu, což přineslo zejména rozdíly v národnostní a sociální struktuře studentů, majících od této chvíle možnost studovat tytéž předměty rovnoprávně $\mathrm{v}$ jednom nebo druhém zemském jazyku. ${ }^{6}$

Další změnu přinesl rok 1897, kdy nastoupily na filozofické fakulty první studentky, ${ }^{7}$ o tři roky později začaly dívky studovat rádně i na lékařských fakultách. ${ }^{8} \mathrm{~V}$ obou prípadech se možnost studia týkala všech dívek, at' již byly jakéhokoli vyznání.

Vznik Československa v roce 1918 žádné zásadní změny v systému vzdělávání nepřinesl, rozšriřily se ale stávající možnosti. Vznikly nové univerzity v Brně a Bratislavě, kam odešli i někteří pedagogové z pražské české univerzity, přibyly možnosti širší zahraniční spolupráce, výjezdy do ciziny apod. Pokud jde o studenty, do Prahy přišli studovat posluchači a posluchačky z východu a jihu Evropy, kteří v prvních poválečných letech tvořili významné procento studentů $\mathrm{v}$ rámci všech československých vysokých škol. Mezi nimi bylo značné procento studentů a studentek židovského vyznání, kteří studovali na českých i německých vysokých školách. Významně také narostla spolková aktivita všech studentů. 9

Jediná vnitřní organizační změna, která v rámci dvou pražských univerzit (v roce 1920 získala česká univerzita název „Karlova universita“) v Praze nastala, bylo vyčlenění

4 Kromě nich byla součástí ústavy další právní pořízení, vše je publikováno např. na $<$ http://alex.onb.ac.at/cgi -content/alex apm=0\&aid=rgb\&datum $=18670004 \&$ seite $=00000389 \&$ zoom $=2>$ (cit. 29. 9. 2020).

5 Viz čl. 14, 15, 16: < https://is.muni.cz/el/1422/jaro2015/MP201Zk/um/web/doc/19-stoleti/Prosincova_ustava 1867.pdf $>$ (cit. 21. 3. 2020)

6 Jan HavráneK, Budováni české univerzity a její působení jako centra české vzdělanosti, in: týž (ed.), Dějiny Univerzity Karlovy, III, 1802-1918, Praha 1997, s. 183-196; Jiří PeŠEK - Alena MíšKovÁ - Ludmila HLAvÁčKOVÁ, Německá univerzita po rozdělení, tamtéž, s. 305-310.

7 První promovanou ženou na české univerzitě, doktorkou filozofie, se stala 17. června 1901 Marie Zdenka Baborová. Marie ŠTEMBERKovÁ, Doktorky filozofie a mediciny na pražské univerzitě od r. 1901 do konce první světové války, in: Jiř́ Pešek - Václav Ledvinka (edd.), Žena v dějinách Prahy. Sborník př́ispěvků z konference Archivu hl. m. Prahy a Nadace pro gender studies 1993 (Documenta Pragensia 13), Praha 1996, s. 213-234, zvl. s. 213 a 219.

8 Prvními lékařkami českého původu byly Bohuslava Kecková a Anna Bayerová, ty však promovaly ve Švýcarsku. První z nich v roce 1880 v Curychu, druhá o rok později v Bernu. Petr SvoBodnÝ - Ludmila HLAvÁčKovÁ, Dějiny lékařství věeských zemích, Praha 2004, s. 148-149.

$9 \mathrm{~K}$ postavení německé lékařské fakulty a oborů na ní medikům přednášených pak viz např. Jiří PEŠEK - Alena MíŠKovÁ - Petr SvoBOdnÝ - Jan JANKo, Německá univerzita v letech 1918-1939, in: Jan Havránek - Zdeněk Pousta (edd.), Dějiny Univerzity Karlovy, IV, 1918-1990, Praha 1998, s. 181-184, 200-205; Ludmila HLAVÁČKOvÁ, Druhá česká a německá interní klinika v Praze v dobách přednostenství E. Maixnera, J. Thomayera a R. Jaksche, Acta Universitatis Carolinae - Historia Universitatis Carolinae Pragensis (dále AUC-HUCP) 51/2, 2011, s. 11-43; Emilie TĚŠínSKÁ - Ludmila HLAVÁČKOvÁ, Z historie výuky pro mediky na pražských univerzitách, AUC-HUCP 51/1, 2011, s. 11-57; Petr SvobodnÝ, Chemie na lékařských fakultách v Praze, Vidni a Lipsku, AUC-HUCP 50/2, 2010, s. 15-86; Ludmila HLAVÁČKOVÁ, Počátky neurologie na pražských lékařských fakultách a založení neurologických klinik, AUC-HUCP 59/2, 2019, s. 11-42. 
samostatných př́rodovědeckých fakult - české a německé, takže každá z univerzit měla od té doby po pěti fakultách. ${ }^{10}$

Přijetí norimberských zákonů ${ }^{11}$ v Protektorátu Čechy a Morava nařízením rŕíšského protektora z 21. června 1939, jemuž předcházely útoky nejen na židovské studenty, ale i pedagogy, neoficiální propouštění zaměstnanců židovského původu atd. z německé univerzity již od počátku druhé poloviny třicátých let, v souvislosti s její nacifikací, ukončilo drastickým způsobem 150leté období vzestupu této skupiny obyvatelstva mezi intelektuální a společenskou elitu. ${ }^{12}$ Židovským dívkám byl vyměřen ještě kratší čas - necelých čtyřicet let, kdy mohly studovat na filozofické, lékařské, právnické nebo prŕrodovědecké fakultě a uplatnit své schopnosti v praxi.

\section{Studentky židovského vyznání na pražské univerzitě}

I přes pouhá ani ne čtyři desetiletí, po něž se mohly židovské dívky zapisovat ke studiu na jednotlivých fakultách jak české, tak i německé univerzity, ${ }^{13}$ nejde o nikterak zanedbatelné počty, jak dokládají matriky absolventů jednotlivých fakult ze sledovaného období. ${ }^{14}$ Podívejme se tedy nejprve blíže na konkrétní čísla, jež nám poskytují katalogy jednotlivých fakult obou univerzit. Vzhledem k rozdělení univerzity sledujeme zvlášt' údaje pro českou a německou univerzitu, přičemž pro českou univerzitu vycházíme z údajů pro období od roku 1901 (první promoce) do akademického roku 1923/1924 (včetně). Pokud jde o německou univerzitu, zahrnují údaje léta 1908 (rovněž první promoce) až též do akademického roku 1923/1924 (včetně). Věnujeme tedy pozornost období šesti let po ukončení první světové války, kdy měly šanci odpromovat i dívky, které během války masivněji nastoupily ke studiu, jak ukazují tabulky dále.

10 Jan HAVRÁNEK, Univerzita na prahu samostatné republiky, in: týž (ed.), Dějiny Univerzity Karlovy, III, s. 19-23; Břetislav Fajkus, Přrirodovědecká fakulta 1920-1945, tamtéž, s. 163-164.

11 V Německu v Norimberku vyhlášeny již 15. záŕí 1935. K počátkům prosazování mladých žen z židovského prostředí ve světě vědy viz Jiř́ PEŠEK, Dr. Alice Hofmann. K počátkům ženské védecké emancipace na Německé univerzitě v Praze, in: Tomáš Jiránek - Karel Rýdl - Petr Vorel (eds.), Gender history - to přece není nic pro feministky, Pardubice 2017, s. 287-296, 271-280.

12 Alena MíšKovÁ, Německá univerzita za druhé světové války, in: J. Havránek - Z. Pousta (edd.), Dějiny Univerzity Karlovy, IV, s. 213-218; тÁž, Německá (Karlova) univerzita od Mnichova k 9. květnu 1945, Praha 2002.

13 Od promoce první židovské studentky na filozofické fakultě české univerzity v červnu 1907 do přijetí norimberských zákonů, resp. do zavření vysokých škol 17. listopadu 1939, přičemž poslední židovská studentka promovala na české lékařské fakultě 30. června 1939 (Gertruda Groarová, nar. 24. 2. 1914 v Lipníku n. Bečvou) a na německé to bylo v rámci skupinové promoce jen mediků židovského vyznání dne 14. února 1939. Tehdy promovaly s několika muži i čtyři lékařky (Ilse Schlesinger, nar. 27. 8. 1914 v Těšíně), Ruth Steinhart (nar. 23. 6. 1912 v Brně), Elsa Katzberg (nar. 6. 6. 1914 v Jablonci nad Nisou) a cizinka Gusta Naftalison (nar. 4. 8. 1915 v Botosani, Moldávie). Archiv Univerzity Karlovy (dále AUK), Matrika doktorů Univerzity Karlovy (1937-1939), inv. č. 10, s. 4875, online viz <https://is.cuni.cz/webapps/archiv/public /book/bo/1924165860347712/479/?lang=cs\&pagenr2=4875> (cit. 26. 3. 2020); Matrika doktorů Německé univerzity v Praze (1936-1939), inv. č. 6, s. 358-360, online viz <http://is.cuni.cz/webapps/archiv/public/book /bo/1689099411327390/362/?lang=cs> (cit. 27. 3. 2020).

14 AUK, Matriky doktorů české Karlo-Ferdinandovy Univerzity, inv. č. 2-4; Matrika doktorů německé Karlo-Ferdinandovy univerzity (1904-1924), inv. č. 3. Online viz <https://is.cuni.cz/webapps/archiv /public/books/bs/1531715692133246/?lang=cs>; a <https://is.cuni.cz/webapps/archiv/public/books/bs /1201577654060565/?lang=cs> (cit. 21. 3. 2020). Počet zapsaných ke studiu byl nepochybně vyšší, vzhledem k absenci pramenů (studentských katalogů) však nelze stanovit, o jak velký rozdíl se jednalo. 
Přestože většina židovských studentek byla zapsána na univerzitě německé (viz dále), byly pro srovnání a objasnění rozdílné situace na obou univerzitách zpracovány i údaje pro univerzitu českou, byt’ z hlediska celkového pohledu na osudy absolventek nemají prakticky žádný dopad. ${ }^{15}$

Předmětné období bylo zvoleno i vzhledem k tomu, že absolventky lékařských fakult české i německé univerzity byly ve třicátých letech minulého století, tedy v období nástupu národního socialismu v Německu, v době, kdy jeho ideologie začala dopadat i na Československo, zpravidla již léta praktikujícími zkušenými lékařkami.

Celkem promovalo na české univerzitě v letech 1901-1923/24 čtyři sta sedmdesát pět posluchaček, na německé pak v letech 1908-1923/24 absolvovalo celkem 206 studentek. Jak již bylo uvedeno výše, jako první začaly dívky studovat na filozofických fakultách obou univerzit, na německé v letech 1908 až 1924 činil počet absolventek filozofických studií 62, 18 posluchaček absolvovalo studia prírodovědecká (od listopadu 1920), jedna studentka práva (v listopadu 1923 absolvovavší Käthe Schwarz). ${ }^{16} \mathrm{Na}$ české univerzitě promovalo do konce akademického roku 1923/24 celkem 99 absolventek filozofické fakulty různých oborů, 348 lékařek, 20 právniček a 8 doktorek prrírodních věd. Co se týká lékařské fakulty, resp. fakult, jež byly otevřeny dívkám v roce 1900, získalo na české lékařské fakultě doktorát medicíny do konce akademického roku 1923/24 včetně 348 žen, ${ }^{17}$ z německé vzešlo 125 lékařek.

Podívejme se nyní, jak vychází z hlediska dat porovnání židovských studentek s př́íslušnicemi většinového křest’anského obyvatelstva. Zatímco na české univerzitě promovaly první absolventky většinové části obyvatelstva již v roce 1901 (viz výše), příslušnice mojžíšského vyznání až v roce $1907,{ }^{18}$ na německé univerzitě to bylo v prvním př́ípadě (filozofka, vůbec první doktorka na německé univerzitě) v listopadu 1908, ${ }^{19}$ ve druhém (lékařka) pak v ř́ínu následujícího roku. ${ }^{20}$ Ale zatímco na německé univerzitě byla první židovská absolventka zároveň i první absolventkou lékařské fakulty, první doktorát

15 Při dalším bádání počítáme s rozšířením výzkumu pro celé období, tzn. do přijetí norimberských zákonů, resp. až do uzavření vysokých škol 17. listopadu 1939 či ještě přesněji do zápisu poslední studentky židovského vyznání. I v př́ípadě, že studenti - příslušníci židovské minority - absolvovali studia v období necelého půl roku mezi přijetím norimberských zákonů 21. června 1931 a uzavřením vysokých škol, je v matrice absolventů u každého z nich připojeno razítko s informací o zákazu výkonu profese na území Protektorátu Čechy a Morava, a to v následujícím znění: „Zřekl se práva vykonávat lékařskou praxi na územi Čech a Moravy a není na tomto územi k jejímu výkonu oprávněn, leč by dosáhl oprávnění k výkonu lékařské praxe podle $\S 4$ nebo §6 zákona z 28. června 1929, č́s. 114 Sb. Z. a n." Online viz <http://kramerius-vs.nkp.cz/view /uuid:806260b0-bd13-11e9-aa95-5ef3fc9ae867?page=uuid:7bc8f810-bd37-11e9-b601-005056825209> (cit. 21. 3. 2020).

16 Käthe Schwarz (nar. 3. 10. 1900, Úštěk). AUK, Matrika (1904-1924), inv. č. 3/843, online viz <https://is.cuni .cz/webapps/archiv/public/book/bo/1971898055542710/853/?lang=cs\&pagenr2=843> (cit. 21. 3. 2020). Studium práv na české univerzitě bylo ženám zpř́istupněno až po roce 1918. J. HavrÁNEK, Dějiny Univerzity Karlovy, III, s. 194.

17 První českou absolventkou medicíny se stala v roce 1902 Anna Honzáková, jejíž životní prríběh je dostatečně známý. P. Svobodný - L. HlaváčKová, Dějiny lékařství, s. 149; Eva Uhrová, Anna Honzáková a jiné dámy, Praha 2012.

18 Anna Fischerová (nar. 28. 12. 1881, Kolín). Marie ŠTEMBERKovÁ, Doktorky filozofie a medicíny, s. 221.

19 Charlotte Weil (nar. 27. 8. 1886, Praha-Bubeneč), z rodiny univerzitního profesora chirurgie na německé univerzitě Karl Weila. AUK, Matrika (1904-1924), inv. č. 3/104. Online viz <https://is.cuni.cz/webapps/archiv /public/book/bo/1971898055542710/108/?lang=cs\&pagenr2=104> (cit. 21. 3. 2020).

20 Else Raubitschek (nar. 30. 5. 1885, Karlín), z pražské rodiny MUDr. Ignaze Raubitscheka. AUK, Matrika (1904-1924), inv. č. 3/138. Online viz <https://is.cuni.cz/webapps/archiv/public/book/bo $/ 1971898055542710 / 142 /$ ?lang $=\mathrm{cs}>$ (cit. 21. 3. 2020). 
medicíny na české lékařské fakultě získala studentka židovského vyznání až v roce 1915 . $^{21}$ Do konce námi sledovaného období, tj. konce akademického roku 1923/24, absolvovalo lékařskou fakultu na české univerzitě sedmnáct studentek mojžíšského vyznání, tj. 4,9\%, podíl absolventek židovského vyznání na celé české univerzitě ve stejném období činil jednadvacet dívek, tedy 4,4 \% všech promovaných doktorek.

Zcela odlišné poměry vykazuje pro sledované období německá univerzita, na níž je podíl židovských studentek výrazně vyšší - činil více než polovinu z celkového počtu absolventek (56,3\%), zastoupení židovských lékařek představovalo dokonce $64 \%$. Pokud jde o absolventky filozofické fakulty, jejich podíl byl 45,2 \% (osmadvacet z dvaašedesáti), u fakulty př́rodovědecké pak 44,4 \% (sedm z osmnácti). Pro exaktnější porovnání dat je v následující tabulce uveden poměr absolventek české a německé univerzity pro shodné časové období, tzn. od promoce první ženské absolventky na univerzitě v roce 1901 do konce akademického roku 1923/24.22

Tab. 1: Podíl promovaných doktorek (PhDr., MUDr., RNDr., JUDr.) české a německé univerzity podle náboženské př́íslušnosti v letech 1901-1924

\begin{tabular}{|c|c|c|c|c|c|c|c|c|}
\hline \multicolumn{4}{|c|}{ Česká univerzita } & \multicolumn{3}{c|}{ Německá univerzita } \\
\hline $\begin{array}{c}\text { ř́́m. } \\
\text { katolické }\end{array}$ & evangelické & židovské & pravosl. & bez vyzn. & $\begin{array}{c}\text { ř́́m. } \\
\text { katolické }\end{array}$ & evangelické & židovské & $\begin{array}{c}\text { bez } \\
\text { vyzn. }\end{array}$ \\
\hline $\begin{array}{c}330 \\
(69,5 \%)\end{array}$ & $\begin{array}{c}42 \\
(8,8 \%)\end{array}$ & $\begin{array}{c}21 \\
(4,4 \%)\end{array}$ & $\begin{array}{c}14 \\
(2,9 \%)\end{array}$ & $\begin{array}{c}68 \\
(14,3 \%)\end{array}$ & $\begin{array}{c}68 \\
(33 \%)\end{array}$ & $\begin{array}{c}17 \\
(8,3 \%)\end{array}$ & $\begin{array}{c}116 \\
(56,3 \%)\end{array}$ & $\begin{array}{c}5 \\
(2,4 \%)\end{array}$ \\
\hline
\end{tabular}

Tab. 2: Podíl absolventek lékařské fakulty české a německé univerzity podle náboženské příslušnosti v letech 1901-1924

\begin{tabular}{|c|c|c|c|c|c|c|c|c|}
\hline \multicolumn{4}{|c|}{ Česká lékařská fakulta } & \multicolumn{4}{c|}{ Německá lékařská fakulta } \\
\hline $\begin{array}{c}\text { ř́ím. } \\
\text { katolické }\end{array}$ & evangelické & pravosl. & židovské & bez vyzn. & $\begin{array}{c}\text { řím. } \\
\text { katolické }\end{array}$ & evangelické & židovské & $\begin{array}{c}\text { bez } \\
\text { vyzn. }\end{array}$ \\
\hline $\begin{array}{c}241 \\
(69,3 \%)\end{array}$ & $\begin{array}{c}34 \\
(9,8 \%)\end{array}$ & $\begin{array}{c}13 \\
(3,7 \%)\end{array}$ & $\begin{array}{c}17 \\
(4,9 \%)\end{array}$ & $\begin{array}{c}43 \\
(12,3 \%)\end{array}$ & $\begin{array}{c}35 \\
(28 \%)\end{array}$ & $\begin{array}{c}8 \\
(6,4 \%)\end{array}$ & $\begin{array}{c}80 \\
(64 \%)\end{array}$ & $\begin{array}{c}2 \\
(1,6 \%)\end{array}$ \\
\hline
\end{tabular}

Z uvedených tabulek je patrné, že z hlediska náboženské příslušnosti byla na německé části univerzity její struktura poněkud pestřejší. Zatímco na českou univerzitu se zapisovaly zejména dívky z katolických rodin (ve sledovaném období bylo pouze šest absolventek židovského původu, z toho čtyři byly na lékařské fakultě - jedna z Kolína a tři z Haliče), na německé univerzitě bylo poměrné zastoupení absolventek zcela odlišné. S tím ostatně koresponduje i výrazný podíl Židů v profesorském sboru, zvláště pak právě na lékařské fakultě a obdobně i na fakultě právnické. Ten se začal ale měnit s postupně narůstajícím antisemitismem během třicátých let, kdy jak zástupci pedagogického sboru mojžíšského vyznání, tak studenti byli stále častěji vystavováni útokům především pravicových studentských

21 Žofie Wepperová (nar. 27. 10. 1891, Lvov). AUK, Matrika (1908-1916), inv. č. 3/1442. Online viz<https:// is.cuni.cz/webapps/archiv/public/book/bo/1569619878951260/426/?lang=cs\&pagenr2=1422> (cit. 21.3. 2020).

22 Porovnávat počty s celkovým počtem absolventů v daném období není vzhledem k rozsahu materiálu reálné a v dané souvislosti ani relevantní. Mnohem zajímavější bude sledovat křivku vývoje v následujících letech, v období první republiky až do uzavření vysokých škol. 
radikáli̊. Zároveň, jak uvádí J. Pešek a N. Lohmann, specifikem pražské univerzity bylo přenášení protižidovských výpadů do sporu česko-německého, „který většinou bezpečně překrýval čistě antisemitskou motivaci. Nacionalita byla pro absolutní většinu současníkủ podstatně významnějši než náboženská př́slušnost nebo dokonce 'rasový pưvod'jednotlivců. Ti byli častěji rozlišováni jako 'Češi 'nebo 'Němci'než zařazováni do nábožensko-rasových kategorii. " 23 Rasisticky motivované útoky, nezř́íka pod rouškou nacionalistických sporů, nabývaly postupně stále otevřenější formu, zvláště od počátku třicátých let, kdy se v sousedním Německu dostali k moci nacisté. Stupňující se opatření vůči židovskému obyvatelstvu čím dál více doléhala i na Československo. Exaktní údaje, jak se měnící situace postupně v čase promítla do struktury studentů a pedagogického sboru na jednotlivých fakultách však zatím, žel, nemáme $\mathrm{k}$ dispozici.

Kromě početního zastoupení př́islušnic jednotlivých vyznání na obou univerzitách není bez zajímavosti jejich původ. Zatímco absolventky české univerzity pocházely většinou z Čech a Moravy, z jiných částí monarchie nacházíme v matrikách z daného období pouze pět absolventek $\mathrm{z}$ Haliče, jednu z Lublaně, cizinkou v pravém slova smyslu byla jen jedna absolventka původem z Baku, místa původu posluchaček univerzity německé byla mnohem pestřejší. Kromě Čech, Moravy a Slezska přicházely do Prahy i z dalších oblastí monarchie - velká část z Haliče, ale i z Vídně, dále z Uher, Srbska a dokonce z Německa.

Co se týká sociálního původu absolventek lékařských fakult, jsme u české univerzity limitováni jejich nízkým počtem, přesto ale pokud jde o lékařskou fakultu, pocházely $\mathrm{z}$ obdobného prostředí jako absolventky německé univerzity. Podle údajů u promovaných lékařek zde uvedených je zřejmé, že jejich rodiny prŕslušely v naprosté většině k vyšší střední třídě. Vedle obchodníků či obchodních zástupců je zastoupen i poměrně vysoký počet univerzitně vzdělaných otců - lékařů a právníků.

\section{Prameny $\mathrm{k}$ profesnímu uplatnění lékařek}

Budeme-li vycházet z předpokladu, že po absolvování studia se většina těchto lékařek začala věnovat dřive či později (s ohledem na př́padné mateřské povinnosti) své profesi, ve třicátých letech minulého století měly za sebou již odpovídající zkušenosti a praxi nabytou v soukromých ordinacích, nemocnicích či laboratořích, některé byly na vrcholu své profesní kariéry. Je značně obtížné zmapovat osudy všech lékařek a dalších intelektuálek, které do sledované skupiny patří, $\mathrm{v}$ řadě př́padů se to patrně ani nepodaří vzhledem torzovitosti či nedostupnosti pramenů. Dř́ive, než se pokusíme alespoň v základních rysech na několika prríkladech přibližit osudy některých z nich, je nezbytné alespoň rámcově přiblížit hlavní skupiny pramenů, $\mathrm{z}$ nichž lze s větším či menším úspěchem sestavit mozaiku těchto osudů.

Při sledování osudů absolventek pražské univerzity, v našem př́ípadě lékařek, jsme vycházely primárně z univerzitních matrik v Archivu Univerzity Karlovy, ${ }^{24}$ dále z policejních

23 S poděkováním autorům převzato z rukopisného textu Židovští rektoři a děkani Německé univerzity v Praze 1882_ 1938. Dále viz Jiří PešEK - Nina LoHMAnN, Quido Goldtschmiedt (1850-1915). Ein jüdischer Chemiker zwischen Prag und Wien, in: Friedrich Edelmayer - Margarete Grandner - Jiří Pešek - Oliver Rathkolb (Hgg.), Über die österreichische Geschichte hinaus. Festschrift für Gernot Heiss zum 70. Geburtstag, Wien 2012, s. 79-110.

24 Dostupné online - viz pozn. 14. 
konskripcí uchovávaných v Národním archivu (fond Policejní ředitelství Praha II - evidence obyvatelstva) a spisů uložených tamtéž (fond Policejní ředitelství Praha II - všeobecná registratura). ${ }^{25}$ Spisy k jednotlivým osobám, avšak pouze torzovitě dochované, jsou k dispozici i v Archivu bezpečnostních složek. Pokud jde o písemnosti v Národním archivu, tak u celé řady absolventek kromě policejní přihlášky není dochována žádná další písemná agenda, u jiných jsou k dispozici sice poměrně solidní konvoluty spisů, ty však zpravidla neobsahují žádné údaje týkající se profesní činnosti jednotlivých lékařek. Některé doplňující informace lze dohledat i ve spisech rodinných príslušníků, zpravidla manželů, většinou v souvislosti s žádostmi o udělení pasu pro jednotlivé členy rodiny či jako součást žádostí o vystěhování. Tyto písemnosti představují také hlavní obsah uvedených spisů. Co se týká podrobnějších informací vztahujících se k profesi, jsou uváděny, žel, zpravidla pouze u otce jako hlavy rodiny.

Důležitým zdrojem informací o absolventkách lékařských fakult jsou i Kalendáře československých lékařŭ, které vycházely pro každý kalendářní rok po celou dobu první i druhé Československé republiky nákladem Ústřední jednoty československých lékařu. Přinášely přehled všech zdravotnických zařízení a vedle toho i jmenný seznam činných i neaktivních lékařu podle jednotlivých regionů. Zdánlivě je proto jednoduché s jejich pomocí dohledat lékařky, tím spíše, že Kalendáře uvádějí i rodná př́ijmení vedle př́ijmení vyvdaných. Ve trricátých letech najdeme v Kalendárích i rok promoce daného lékaře/lékařky.

Pro účely našeho výzkumu byly zpracovány roky 1928 a 1936. Rok 1928 byl zvolen proto, že i absolventky z posledních námi zkoumaných promočních let již mohly provozovat stabilizovanější praxi. Rok 1936 byl vybrán s ohledem na ještě relativně stabilnější situaci ve zhoršující se atmosfére hrozícího národního socialismu, primárně ohrožujícího právě populaci židovského původu. Srovnáním jsme chtěly zjistit uplatnění lékařek v oboru. Ukázalo se, že právě Kalendáře jsou pro české absolventky velmi dobrým zdrojem informací, protože zachycují asi tři čtvrtiny lékařek, které vystudovaly Karlovu univerzitu do roku 1924. Zbývající čtvrtinu tvoří zahraniční studentky, které se vrátily pravděpodobně z velké části po promoci zpět domů, a jen minimum českých lékařek. Pro absolventky německé univerzity je situace překvapivě jiná. $Z$ celkového počtu sto dvaceti pěti lékařek, které jsme zachytily na německé univerzitě v období 1908-1924, Kalendár uvádí v obou zkoumaných letech jen patnáct $\mathrm{v}$ jednom nebo druhém roce ( $\mathrm{z}$ toho je devět uvedeno shodně $\mathrm{v}$ obou rocích). U dvanácti z nich bylo explicitně uvedeno židovské vyznání.

Není to ale jen otázka (ne)dochování či pro naše účely nedostatečné výpovědní hodnoty pramenů. Zásadní komplikací při zpracovávání rešerší $\mathrm{k}$ jednotlivým absolventkám lékařských fakult ( $v$ našem př́ípadě především německé), jsou rodná jména. Absolventky jsou $\mathrm{v}$ univerzitní matrice totiž zapsány pod jménem užívaným za svobodna. Pouze výjimečně byly $\mathrm{v}$ době promoce provdány a máme tak $\mathrm{k}$ dispozici jméno $\mathrm{z}$ doby po uzavření sňatku. Bezmála detektivní pátrání po informacích, bez nichž nelze v dalším bádání postoupit, vede přses uvedené policejní konskripce a přihlášky. To se ale dosud podařilo (formou sond) pouze u žen, které pocházely z Prahy či po promoci působily určitou dobu v Praze a lze je tak podchytit $\mathrm{v}$ uvedených písemných pramenech.

$25 \mathrm{~V}$ této souvislosti patří poděkování za neobyčejnou vstřícnost a pomoc s dohledáváním informací kolegyni Jitce Prajzlerové z Národního archivu. Pokud jde o další písemnosti zde uložené, bude nezbytné do budoucna (i s ohledem na rozšíření časového záběru) využít prameny lékařských komor. 
Je tedy zřejmé, že nepoměrně komplikovanější situace nastává u „venkovských“ absolventek a ještě složitější situace (a v řadě př́ípadů asi i neřešitelná s ohledem na (ne)dostupnost i torzovité dochování pramenů) je u absolventek odcházejících po absolvování studia zpět do míst svého původu (na území dnešního Polska, Slovenska, Rakouska, Německa či Mad'arska). S ohledem na tuto skutečnost jsme se primárně (nikoli však bezvýhradně) zaměřily na absolventky pocházející z Čech a působící v Čechách a v Praze zvláště.

Pro sledování osudů jednotlivých absolventek lékařského studia na univerzitě v době druhé světové války představuje kromě již uvedených pramenů zásadní zdroj informací databáze obětí holocaustu. ${ }^{26} \mathrm{Ta}$ ale zahrnuje pouze ty osoby, které prošly sběrným táborem v Terezíně, to znamená primárně osoby z Protektorátu Čechy a Morava, později i z jiných zemí (ale jen ve velmi omezeném rozsahu) - ze Slovenska, Německa, Rakouska, Nizozemí, Dánska. Pokud jde o židovské obyvatelstvo z východu, především z Haliče, odkud jich byl mezi studentkami a posléze absolventkami nemalý počet, tak pro většinu z nich Terezín nebyl ani přestupní stanicí dále na východ. A pakliže se jim nepodařilo včas uprchnout, jejich osud byl prakticky zpečetěn. ${ }^{27}$ Dílčí informace lze nalézt v seznamech osvětimských obětí (viz př́ílad níže - Marie Groszman, provd. Stacha).

\section{Př́́klady biogramů}

Má-li být řeč o lékařkách židovského původu z českých zemí, jejichž osud nějakým způsobem poznamenala politická situace $\mathrm{v}$ Evropě mezi válkami, nelze začít jinak než s Gerty Therese Radnitz, provdanou Cori (1896 Praha - 1957 St. Louis, USA), nositelkou Nobelovy ceny za fyziologii a medicínu v roce 1947 (sdílenou s manželem, rovněž pocházejícím z Prahy, absolventem pražské německé univerzity, ovšem z katolické rodiny -Carlem Cori, a s argentinským fyziologem Bernardem Houssay-em ${ }^{28}$ ). Její osud byl už v literatuře zpracován vícekrát. ${ }^{29}$ Záznamy o studiu Gerty Therese Radnitz i Carla Coriho jsou uloženy v Archivu Univerzity Karlovy, kde je lze dohledat v katalozích studentů lékařské fakulty německé univerzity ${ }^{30} \mathrm{a} v$ matrikách doktorů lékařské fakulty téže univerzity, na níž Gerty nastoupila v roce $1914 .{ }^{31}$ Zde se budoucí manželé seznámili a po absolvování

$26<$ https://www.holocaust.cz/databaze-obeti/> (cit. 22. 3. 2020).

27 Dalším př́kladem pramenů, které by napomohly při doplňování informací, mohou být písemnosti nacházející se v soukromých rukou.

28 Nobelova cena jim byla udělena za objev průběhu katalytické přeměny glykogenu. Viz <https://www.nobelprize.org/prizes/medicine/1947/summary/> (cit. 22. 3. 2020).

29 Např. Sharon Bertsch McGrayne - Gertrude Belle Elion, Nobel Prize Women in Science, Washington, DC 1998, s. 93-116; Marelene RAYNER-CANHAM - Geoffrey RAYNER, Women in chemistry: Their changing roles from alchemical times to the mid-twentieth century, Danvers, MA 1998, s. 150-152; Roy PorTER, Cori, Carl Ferdinand and Gerty Theresa, in: The Biographical Dictionary of Scientists, 2nd edition, New York 1994, s. 144; Ludmila HLAvÁČKovÁ, Manželé Coriovi-jediní nositelé Nobelovy ceny za medicínu z Prahy, Dějiny věd a techniky 31/1, 1998, s. 61; Pavel ČECH, Manželé Coriovi, pražští rodáci s Nobelovou cenou, Časopis lékařů českých 140/1, 2001, s. 26-30; elektronicky dostupné např. <https://www.nap.edu/read/2037/ chapter/8\#118> (cit. 23. 3. 2020).

30 Archivní pomůcky elektronicky dostupné na <https://udauk.cuni.cz/ARCH-33.html> (cit. 23. 3. 2020).

31 Karl Ferdinand Cori (nar. 5. 12. 1896, Praha), AUK, Matrika (1904-1924), inv. č. 3/487. Online viz <http:// is.cuni.cz/webapps/archiv/public/book/bo/1971898055542710/497/?lang=cs $>$ a Gerty Theresa Radnitz (nar. 15. 8. 1896, Praha), tamtéž, inv. č. 3/465. Online viz <http://is.cuni.cz/webapps/archiv/public/book/ bo/1971898055542710/475/?lang=cs\&pagenr2=465> (cit. 23. 3. 2020) 
studií a získání doktorátu se vzali. Jako Židovka a katolík nenašli pro svůj vztah pochopení ve vlastních rodinách, a proto přesídlili začátkem dvacátých let do Vídně, ${ }^{32}$ kde doufali najít přátelštější prostředí i lepší pracovní podmínky. Poválečná krize a chudoba tehdejšího Rakouska je brzy vedla dále. V roce 1922 přesídlili do Spojených státu amerických, kde získal Carl v Bufallu místo biochemika, a začali svou kariéru na zdejším ústavu pro výzkum karcinomu (the State Institute for the Study of Malignant Diseases, založen v roce 1912).

Gerty se zabývala výzkumem působení hormonů štítné žlázy a vlivu rentgenového záření na lidský metabolismus. Své výzkumy publikovala v samostatných studiích. V roce 1931 Coriovi přesídlili z Bufalla do St. Louis, kde Gerty získala profesuru nejprve farmakologie, v roce 1947 biochemie. Její poslední studie vyšla ještě v roce její smrti. V roce 1947 získala s manželem a fyziologem Bernardo Houssayem Nobelovu cenu za fyziologii a lékařství za objev funkce hormonů předního laloku hypofýzy při metabolismu cukrů. Měla jediného syna, Carla Thomase (nar. 1936), který ve stopách svých rodičů zasvětil svůj život biochemii. 33

Gerty Cori tvoří samozřejmě absolutní špičku při popisu uplatnění pražských lékařek židovského původu, vlastně je špičkou ledovce, rozprostírajícího se mnoha směry.

Ve dvacátých letech minulého století už bylo celkem běžné, že absolventky vysokoškolského studia nastoupily odbornou kariéru, $\mathrm{v}$ prŕpadě lékařek $\mathrm{v}$ ordinacích, nemocnicích nebo laboratořích větších, např. farmaceutických firem. Pokud si otevřely vlastní ordinace, bylo to často díky pomoci rodiny - nebylo výjimkou, nýbrž spíše pravidlem, že samy pocházely z rodiny lékaře, nebo se za lékaře provdaly a mohly tímto způsobem spolupracovat $\mathrm{v}$ rámci rodiny. Narodil-li se potomek, ani poté nemusely kariéru ukončit, často pokračovaly v nastoupené cestě.

Začaly jsme připomenutím nejvýznamnější absolventky pražské německé lékařské fakulty, Gerty Cori, roz. Radnitz, jejižz životní osudy byly detailně zmapovány díky tomu, že jsou k dispozici odpovídající písemné prameny, dokumentující její osobní i profesní život, což nepochybně souvisí s výjimečností, dosaženými úspěchy. Žel u většiny ostatních absolventek jsme odkázáni pouze na více či méně útržkovité informace, z nichž je možné postupně skládat mozaiku jejich životních osudů.

Přibližme si na následujících řádcích alespoň některé z nich, jejichž příklady ilustrují osudy i mnohých dalších - emigrace, sebevraždy a především deportace, z nichž v drtivé většině nebylo návratu. Za všechny připomeňme alespoň Marii Stacha, roz. Groszman (nar. 11. 2. 1892, Trenčín - 24. 9. 1942, Osvětim), z rodiny ředitele školy Adolfa Groszmana, promovala v květnu roku 1924. ${ }^{34}$ Stejný osud potkal i Arnoštku Grünberger, roz. Popper, (nar. 25. 2. 1892, Praha-Vinohrady), z rodiny obchodníka Karl Poppera. V prosinci 1916 se provdala za nadporučíka Pavla Grünbergera, dva roky poté, v prosinci 1918, absolvovala studia. ${ }^{35}$ Právě tato poslední skupina je početně nejrozsáhlejší, současně ale i nejobtížněji zmapovatelná, zvláště pokud jde o osudy těch absolventek, které se po ukončení studia

32 Gerty působila jako lékařka v tamní dětské nemocnici.

33 Pavla VošAhlíková a kol., Biografický slovnik českých zemí, 9. sešit, Praha 2008, s. 457-459.

34 Národní archiv Praha (dále NA), Policejní ředitelství Praha II (dále Př II) - evidence obyvatel; AUK, Matrika (1904-1924), inv. č. 3/899. Online viz <https://is.cuni.cz/webapps/archiv/public/book/ bo/1971898055542710/909/?lang=cs\&pagenr2=899> (cit 24. 3. 2020)

35 NA, PR II - evidence obyvatel; AUK, Matrika (1904-1924), inv. č. 3/408. Online viz <https://is.cuni.cz/ webapps/archiv/public/book/bo/1971898055542710/418/?lang=cs\&pagenr2=408> (cit 24. 3. 2020) 
vrátily do svých domovi̊, konkrétně na východ, do Haliče, odkud jich pocházela velká část. Pakliže včas neemigrovaly, byl jejich osud během války zpečetěn. A neprošly-li sběrným táborem v Terezíně, jsou jakékoli další informace zpravidla nedohledatelné.

Př́kladem těch, které zvolily dobrovolný odchod ze života, je Gertrude Bergmann, pocházející z rodiny pražského obchodníka Gustava Bergmanna a jeho manželky Johanny. ${ }^{36} \mathrm{~V}$ roce 1913 absolvovala lékařskou fakultu české Karlo-Ferdinandovy univerzity, kde je v rubrice náboženství uvedeno židovské" (mosaisch). Poté si otevřela zubařskou ordinaci a začala provozovat soukromou praxi. 23. prosince roku 1916 se provdala za ing. Pavla Freunda. Zároveň ve stejný den v souvislosti s uzavřením sňatku konvertovala spolu se svým nastávajícím ${ }^{37}$ k vyznání evangelickému, jak je zjevné z mladší žádosti (z roku 1939) o vydání občanského průkazu, na níž je uvedeno jednak datum sňatku, jednak datum konverze. ${ }^{38} \mathrm{Z}$ roku 1923 je dochována žádost Gertrude, nyní již Freundové, o cestovní pas, jenž jí byl vydán 11. července téhož roku. ${ }^{39}$ Zubařskou praxi vykonávala až do 10 . ledna 1940, jak je zréejmé z konceptu trestního oznámení z 30. května následujícího roku, a to i přes to, že jako Židovka nesměla podle nařízení ze 4. července 1940 provozovat praxi. Odsouzena byla $\mathrm{k}$ dvaceti dnům žaláře a pokutě ve výši $10000,-\mathrm{K} .{ }^{40} \mathrm{Zda}$ uvedenou částku zaplatila a nastoupila do vězení, není známo. Jisté však je, že ani konverze k evangelickému vyznání ji neuchránila před osudem většiny židovské populace. 28. dubna 1942 spáchala sebevraždu, když se otrávila cyankáli ${ }^{41}$, přičemž patrně nejpravděpodobnějším důvodem bylo předvolání do transportu ${ }^{42}$.

Jako poslední jsme záměrně ponechaly skupinu těch lékařek, které přežily válečné běsnění díky včasnému odchodu do emigrace. $\mathrm{V}$ porovnání především $\mathrm{s}$ absolventkami humanitních studií (filozofické fakulty) je zřejmé, že je mezi nimi mnohem vyšší podíl emigrovavších, tedy i přeživších za sledované období. Vzhledem k tomu, že se ale jedná o období poměrně úzce vymezené, jakékoli závěry by byly na základě současného stavu bádání předčasné. Jak ukáže několik následujících př́ikladů, osudy těchto žen byly velmi pestré.

Řada intelektuálů židovského původu opustila střední Evropu mnohem dříve, než Hitlerova mašinérie začala bezprostředně dotírat na jejich vlast. Př́ílad Coriových není zdaleka jediný a lidé neutíkali jen na Západ. Sionismus měl v našem prostř̌edí v té době své zastánce už po několik desetiletí.

36 Gertrude Bergmann (nar. 6. 10. 1888, Praha-Smíchov - 28. 4. 1942, Praha), AUK, Matrika (1904-1924), inv. č. 3/273. Online viz <https://is.cuni.cz/webapps/archiv/public/book/bo/1971898055542710/279/?lang=cs> (cit. 24. 3. 2020); NA, P $\breve{R}$ II - evidence obyvatel.

37 Viz osobní dokumenty Pavla Freunda, online <https://www.geni.com/people/Paul-Freund/60000000 18435563453> (cit. 24. 3. 2020).

$38<$ https://www.holocaust.cz/databaze-dokumentu/dokument/116963-freundova-gertrude-zadost-o-vydani -obcanske-legitimace/> (cit. 24. 3. 2020).

$39<$ https://www.holocaust.cz/databaze-dokumentu/dokument/116962-freundova-gertrude-zadost-o-vydani -cestovniho-pasu/> (cit. 24. 3. 2020).

$40<$ https://www.holocaust.cz/databaze-dokumentu/dokument/116961-freundova-gertrude-trestni-oznameni/> V dané souvislosti bylo vedeno trestní ř́zení i proti jejímu manželovi, jenž byl obviněn, že si nedal označit občanskou legitimaci písmenem ,J“ (=Jude). Online viz <https://www.holocaust.cz/databaze-dokumentu /dokument/116793-freund-paul-trestni-rizeni/> (cit. 24. 3. 2020).

$41<$ https://www.holocaust.cz/databaze-dokumentu/dokument/116964-freundova-gertrude-umrtni-listek/> (cit. 24. 3. 2020).

42 Jeden z transportů (Ao), čítající 1000 osob, byl vypraven z Prahy právě 28. dubna, další s třemi osobami byl vypraven 29. dubna (Ez). 
Jako první v této souvislosti připomeňme Zdenku Ascher (nar. 17. 2. 1890, Praha), pocházející z rodiny pražského obchodníka Leopolda Aschera. ${ }^{43}$ Po promoci v únoru $1918^{44}$ působila jako dětská lékařka. Po sňatku s chemikem Kamilem Kohnem, jenž byl jedním Z významných sionistických aktivistů, se rodina usadila v Ústí nad Labem. Na podzim roku 1938 se jim podařilo odjet do Palestiny, kde po dvou letech pobytu získala Zdenka povolení k provozování lékařské praxe. 45

Druhou lékařkou, jejíž osud připomínáme, je Ida Irma Winternitz. ${ }^{46}$ Narodila se v říjnu roku 1894 v Oxfordu, kde v té době pobývala rodina univerzitního profesora pražské filozofické fakulty, indologa a etnologa evropského významu, Moritze Winternitze (18631937), jenž v akademickém roce 1920/1921 zastával funkci jejího děkana. ${ }^{47}$ Lékařská studia absolvovala 30. dubna 1920. Po studiích se provdala za MUDr. Waltera Marcuse, pocházejícího z německo-židovské rodiny a odešla s ním do Německa. Zde se usadili manželé v Solingenu, kde provozovali společně lékařskou praxi. Na začátku války byl Walter Winternitz odvlečen vzhledem ke svému původu do koncentračního tábora v Dachau. Za to, že Ida zůstala na svobodě, vděčila svému britskému občanství. Po uvěznění manžela se jí podařilo opustit Německo, sehnat finanční prostředky a s jejich pomocí dosáhnout propuštění manžela. Poté se manželé uchýlili do USA. Díky své profesi a schopnostem se jim podařilo $v$ Americe poměrně brzy uchytit a začít společně provozovat lékařskou praxi v Chicagu. ${ }^{48}$

Zcela jiným př́kladem je př́běh Marie Fischer (13. 5. 1898, Duchcov - ?). Pocházela z rodiny váženého duchcovského právníka, JUDr. Rudolfa Fischera. Lékařský titul získala 15. bř̀zna $1924^{49}$ a poté pracovala jako oční lékařka. V roce 1924 se provdala za lékaře Karla Aschera. Manželům se podařilo před blížícím se nebezpečím včas opustit protektorát a podle evidence obyvatel odjet 8 . května 1939 do Londýna, ${ }^{50} \mathrm{kde}$ zůstala po celou válku. V květnu 1945 se jako zdravotnice vrátila do Československa s expedicí, pomáhající lékařskou péčí na osvobozeném území. ${ }^{51}$ Její další osud se zatím nepodařilo zmapovat, stejně jako osudy dalších lékařek židovského původu, které neměly šanci svou profesní kariéru, nastoupenou po absolvování úspěšných vysokoškolských studií, též standardním způsobem ukončit odchodem do penze. Za všechny, jimž se podařilo nějakým

43 Jejím bratrem byl Ernst Ascher (1888-1953), akademický malî́ a obchodník s uměním.

44 AUK, Matrika (1904-1924), inv. č. 3/383. Online viz <https://is.cuni.cz/webapps/archiv/public/book/bo $/ 1971898055542710 / 393 / ?$ lang $=$ cs\&pagenr2 $=383>($ cit. 24. 3. 2020).

45 NA, PŘ II - evidence obyvatel. Dále viz <https://www.pametnaroda.cz/cs/cohen-matti-1924> (cit. 24. 3. 2020).

46 NA, P̌̌ II - evidence obyvatel; AUK, Matrika (1904-1924), inv. č. 3/483. Online viz <https://is.cuni.cz /webapps/archiv/public/book/bo/1971898055542710/493/?lang=cs\&pagenr2=483> (cit 25. 3. 2020). Milada SeKYRKovÁ, Svédomitá studentka a obětavá doktorka: Ida Irma Marcus roz. Winternitz, in: Zdeněk Hojda - Jan Kahuda - Zdeňka Kokošková (edd.), Z archivu ke studentům a zase zpět. Věnováno Ivaně Ebelové k životnímu jubileu, Praha 2021, s. 323-329.

47 J. Havránek, Déjiny Univerzity Karlovy, III, s. 320. Jejím bratrem byl matematik Arthur Winternitz (189319??), profesor pražské Př́rodovědecké fakulty Německé univerzity. Jan HAVRÁNEK - Zdeněk PousTA, Dějiny Univerzity Karlovy, IV, s. 205.

$48<$ https://www.geni.com/people/Ida-Marcus/6000000043584967580> (cit. 25. 3. 2020).

49 AUK, Matrika (1904-1924), inv. č. 3/879. Online viz <https://is.cuni.cz/webapps/archiv/public/book /bo/1971898055542710/889/?lang $=$ cs $>($ cit. 25. 3. 2020).

50 NA, Pर̌ II - evidence obyvatel.

51 Uvedená informace byla vydána pod č. 302-104-2/141 dne 5. dubna 1958, bližší kontext není zřejmý vzhledem k absenci jakýchkoli dalších písemných podkladů - viz opis Archiv bezpečnostních složek, Kartotéka k fondům bývalého Studijního ústavu ministerstva vnitra. 
způsobem uniknout před fatálními důsledky rasového pronásledování, ale u nichž se zatím nepodařilo vypátrat jejich bližší osudy, uved'me ještě alespoň Ernu Frankl (16. 12. 1898, Hodonín - 1974, Izrael), jež absolvovala lékařskou fakultu německé univerzity v dubnu roku $1923 .{ }^{52} \mathrm{~V}$ témže roce se přestěhovala z Prahy do Vídně, kde se provdala za Dr. Otto Teznera. Na přelomu dvacátých a třicátých let se manželé přestěhovali do Palestiny, kde jejich stopy mizí.

\section{Závěr}

S př́klady podobných osudů se setkáváme přirozeně i mimo lékařskou fakultu. Ty však nejsou předmětem této studie. Stejně jako bude nezbytné doplnit a precizovat údaje o jednotlivých lékařkách a rozšriřit především stávající chronologický záběr, bylo by i z hlediska komparace nanejvýš potřebné zmapovat osudy židovských absolventek ostatních fakult české a především německé univerzity. Kromě výše uvedených pramenů, pokud budeme primárně vycházet $\mathrm{z}$ domácích zdrojů, bude nezbytné rozšiřit jejich záběr o profesní almanachy, adresáře, v prŕípadě lékařek i registratury nemocnic a klinik.

\section{Grantová podpora:}

Studie vznikla na Univerzitě Karlově v rámci programu Progres Q 09: Historie - klíč k pochopení globalizovaného světa.

IVANA EBELOVÁ - MILADA SEKYRKOVÁ

\section{Die ersten Medizinabsolventinnen jüdischer Herkunft der Prager Universitäten und ihre Karrieremöglichkeiten zwischen den Weltkriegen}

\section{ZUSAMMENFASSUNG}

Die gleichberechtigte Eingliederung jüdischer Intellektueller der böhmischen Länder bzw. der Habsburgermonarchie in die Strukturen der Mehrheitsgesellschaft (unter Bewahrung ihrer religiösen Zugehörigkeit) war ein Prozess, der relativ lange anhielt. Im Falle weiblicher Intellektueller jüdischer Herkunft war die Situation zudem angesichts der allgemein vorherrschenden Gender-Stereotypen noch komplizierter. Zu einer vollständigen Gleichberechtigung war es bis zum Ausbruch des II. Weltkriegs im wesentlichen nicht gekommen, und nach Kriegsende befand sich die jüdische Gemeinde angesichts des an der jüdischen Bevölkerung während des Krieges begangenen Genozids in einer ungleich schlimmeren Lage als in der Zeit vor der Aufklärung.

Die Bearbeitung eines Themas, das auf die Einbindung von Frauen jüdischer Herkunft in den universitären Bildungsprozess und auf ihre anschließende, gemäß ihrer Qualifikation erfolgte Etablierung in Wissenschaft und Praxis abzielt, ist angesichts der Quellenlage nicht einfach. Für diese Behauptung führt die Studie konkrete Beispiele aus den böhmischen Ländern an, die vor allem aus den Bereichen des Medizinstudiums und der ärztlichen

52 AUK, Matrika (1904-1924), inv. č. 3/796. Online viz <https://is.cuni.cz/webapps/archiv/public/book/bo $/ 1971898055542710 / 806 /$ lang $=$ cs\&pagenr2=796> (cit. 25. 3. 2020). 
Praxis stammen, sowie Beispiele von Frauen mit naturwissenschaftlicher und philosophischer Bildung. Angesichts der Tatsache, dass - von wenigen Ausnahmen abgesehen - die meisten intellektuellen Frauen jüdischer Herkunft an der deutschen Universität Prag studierten, spiegeln sich im Text, verglichen mit den Beispielen der tschechischen Universität, bis zu einem gewissen Grade auch die an der deutschen Universität insbesondere in den 1920er Jahren herrschenden Verhältnisse wider.

doc. PhDr. Ivana Ebelová, CSc.

Katedra archivního studia a PVH FF UK, Praha

ivana.ebelova@ff.cuni.cz

PhDr. Milada Sekyrková, CSc.

Ústav dějin a archiv UK, Praha

milada.sekyrkova@ruk.cuni.cz 